\title{
Arahan Pengembangan Kawasan Desa Wisata di Desa Tulungrejo, Kecamatan Pare, Kabupaten Kediri
}

\author{
Haryo Prasetyo dan Dr. Ing. Ir Haryo Sulistyarso \\ Departemen Perencanaan Wilayah dan Kota, Fakultas Teknik Sipil dan Perencanaan, Institut \\ Teknologi Sepuluh Nopember (ITS) \\ e-mail: haryo.its@gmail.com
}

\begin{abstract}
Abstrak-Desa Tulungrejo memiliki potensi lokal yang di miliki kawasan pedesaan. desa ini memiliki keunikan,keaslian, dan sifat khas yang berkaitan dengan kelompok masyarakat berbudaya yang secara hakiki dapat menarik minat pengunjung. Dari potensi-potensi yang ada di Desa Tulungrejo masyarakat dan pemerintah belum memanfaatkan secara optimal untuk dijadikan kawasan desa wisata, sehingga perlu adannya suatu rumusan arahan guna mengembangkan potensi kawasan desa wisata Tulungrejo Teknik analisis yang di gunakan untuk mencapai tujuan dan sasaran yaitu teknik analisis delphi untuk menentukan faktor pendukung pengembangan desa wisata, analisis deskriptif kualitatif untuk menentukan arahan pengembangan desa wisata tersebut. Hasil dari penelitian ini memiliki potensi untuk dikembangkan sesuai dengan arahan pengembangan secara spasial dan non spasial.
\end{abstract}

Kata Kunci-potensi desa, desa wisata, pengembangan kawasan.

\section{PENDAHULUAN}

$\mathrm{P}$ ARIWISATA adalah seluruh rangkaian kegiatan yang berhubungan dengan gerakan manusia yang melakukan perjalanan atau persinggahan sementara dari tempat tinggal yang didorong beberapa keperluan tanpa bermaksud mencari nafkah tetap. [1] Pariwisata meliputi berbagai jenis yaitu, karena keperluan dan motif perjalanan yang dilakukan bermacam-macam. [2]

Menurut data Kementrian Pariwisata dan Ekonomi Kreatif Republik Indonesia, Pada tahun 2008 kepariwisataan Indonesia berkontribusi terhadap Produk Domestik Bruto (PDB) sebesar Rp. 153,25 trilyun atau 3,09\% dari total PDB Indonesia dan pada tahun 2009, kontribusinya meningkat menjadi 3,25\%.[3]

Sejalan dengan dimanika, perkembangan pariwisata merambah dalam berbagai termologi seperti, sustainable tourismdevelopment, village tourism, dan ecotourism. Halhal tersebut merupakan pendekatan pengembangan kepariwisataan. Salah satu pendekatan pengembangan wisata alternatif adalah desa wisata untuk pembangunan pedesaan yang berkelanjutan dalam bidang pariwisata. [4] Desa wisata sendiri adalah sebuah kawasana pedesaan yang memiliki beberapa karakteristik khusus untuk menjadi daerah tujuan wisata. [5]
Kawasan pedesaan (di Kabupaten Kediri) memiliki proporsi yang sangat luas, dengan penduduk cenderung tersebar, dan perlu mendapat perhatian untuk mendukung terwujudnya keterkaitan, saling mendukung, serta kesetaraan pembangunan dengan kawasan perkotaan. Hal tersebut mendorong terwujudnya program pembangunan perdesaan yang berkelanjutan. [6]

Pengembangan kawasan pedesaan wisata di Kabupaten Kediri diarahkan di Desa Tulungrejo, Kecamatan Pare sebagai kawasan wisata edukasi hal ini dapat di lihat dengan adanya kampung inggris yang berolokasi di Desa Tulungrejo. [7] Selain wisata edukasi, Desa Tulungrejo memiliki komoditas hasil bumi di Provinsi Jawa Timur dan sebagai pusat kegiatan pertanian kawasan agropolitan.

Permasalahan yang terjadi di Desa Tulungrejo adalah masyarakat (sumber daya manusia) yang tidak dapat mengoptimalkan potensi sumber daya alam yang ada. Masyarakat juga kurang memanfaatkan prasarana yang telah ada guna mempromosikan daerah mereka.

Pengembangan daya tarik desa wisata menitikberatkan pada komponen penawaran (supply) komponen permintaan (demand) dari pariwisata dengan mempertahankan keasliannya sebagai ciri khas desa setempat. Arahan pengembangan kawasan pariwisata sebagai desa wisata ini tidak akan berdampak buruk bagi kebudayaan dan nilai-nilai masyarakat setempat. [8] Arahan ini dapat berkembang dan memberikan dampak positif bagi seluruh pihak terkait.

Dengan adanya arahan pengembangan desa dari aspek sumber daya manusia dan sumber daya alam dengan terpadu akan memberikan output yang optimal. Masyarakat diharapkan dapat mengoptimalkan hal-hal terkait guna menunjang berkembangnya Desa Tulungrejo.

\section{METODE PENELITIAN}

\section{A. Jenis dan Pendekatan Penelitian}

Pendekatan yang digunakan dalam penelitian ini adalah berdasarkan pada pendekatan rasionalistik. [9] Jenis penelitian dalam penelitian ini adalah mengunakan metode analisis delphi dan analisis deskriptif kualitatif.

\section{B. Variabel Penelitian}

Penentuan variabel penelitian ditentukan dengan menentukan terlebih dahulu beberapa indikator yang diidentifikasikan secara jelas. [10] Variabel yang akan 
digunakan yaitu berdasarkan faktor pendukung dan juga faktor yang telah ada.

Variabel yang digunakan untuk arahan pengembangan desa wisata di Desa Tulungrejo antara lain:

1. Kegiatan sehari-hari masyarakat sebagai daya tarik.

2. Memfokuskan edukasi dalam bidang agrowisata.

3. Mengintegrasikan aksesbilitas.

4. Mempertahankan kesenian dan kebudayaan tradisioanal.

5. Sarana dan prasarana pendukung.

6. Mengalokasikan pengunaan lahan.

7. Kualitas SDM.

8. Kesempatan investasi untuk sarana dan prasarana.

\section{Populasi dan Sampel}

Untuk menentukan sampel yang digunakan dalam penelitian ini, teknik yang digunakan adalah teknik non probability sampling dengan menggunakan purposive sampling. Purposive sampling bertujuan untuk mengambil subjek bukan didasarkan atas strata, random atau daerah, tetapi didasarkan atas tujuan tertentu. Di mana dalam metode ini langsung menunjuk responden yang berkompeten atau berpengaruh dalam pencapaian sasaran akhir penelitian

\section{Mengidentifikasi Faktor-Faktor yang Ber-pengaruh Terhadap Pengembangan Desa Wisata.}

Analisis Delphi digunakan untuk memperkuat faktorfaktor pengembangan desa wisata, dengan tahap-tahapan dalam analisis yaitu:

1. Wawancara stakeholders, disini yang dimaksidkan ialah stakeholder yang telah ditentukan dalam sampel penelitian.

2. Reduksi dan tampilan data hasil wawancara yang merupakan proses pemfokusan atau meringkas wawancara stakeholders.

3. Penarikan kesimpulan

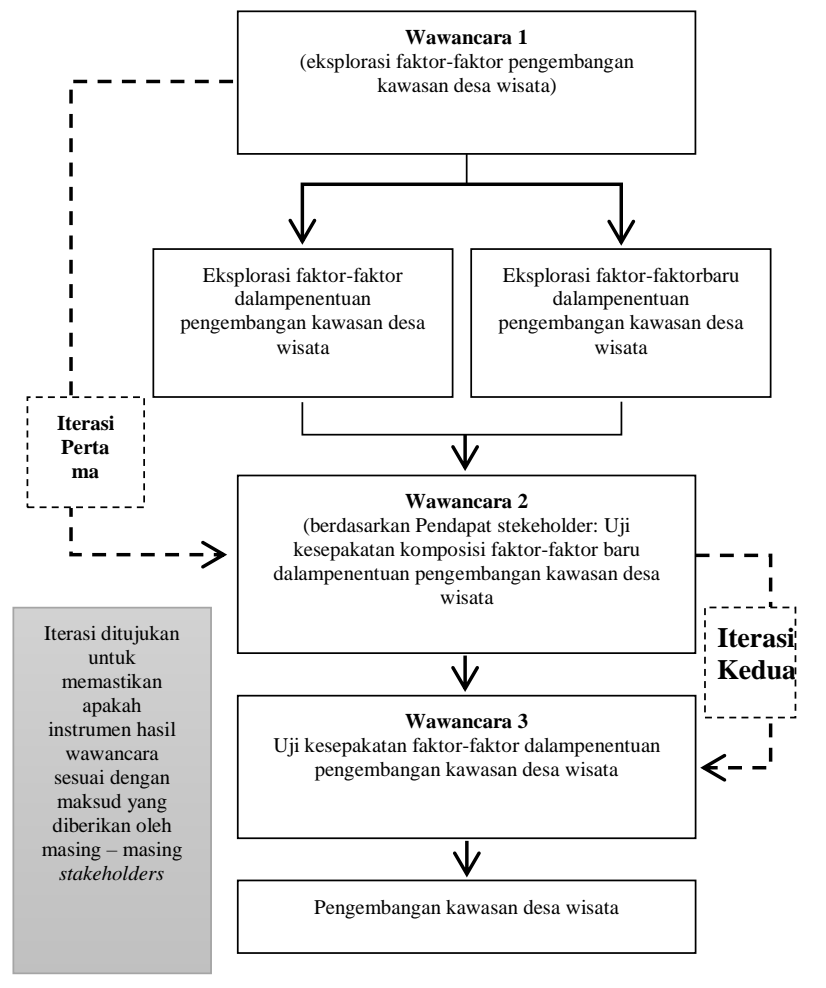

Gambar 1. Bagan Tahapan Analisis Delphi.

\section{E. Arahan Pengembangan Desa Wisata Desa Tulungrejo.}

Untuk menentukkan arahan pengembangan desa wisata dilakukan dengan arahan deskriptif kualitatif. Aspek-aspek yang diprioritaskan menggunakan hasil dari faktor pendukung pengembangan desa wisata, dengan cara membandingkan faktor pengembangan desa wisata,kondisi eksisting, teori terkait dan kebijakan terkait.

\section{HASIL DAN PEMBAHASAN}

\section{A. Identifikasi Faktor-Faktor yang Berpengaruh Terhadap Pengembangan Desa Wisata}

Berdasarkan hasil penelitian didapatkan faktor-faktor yang berpengaruh terhadap pengembangan desa wisata, yaitu:

1. Kegiatan sehari-hari masyarakat sebagai daya tarik desa wisata di Desa Tulungrejo.

2. Fokus edukasi dalam mendukung kegiatan bercocok tanam dan pertanian sebagai atraksi wisata.

3. Kesenian dan budaya tradisional sebagai daya tarik wisata.

4. Aksesbilitas menuju Desa Tulungrejo yang kurang terintegrasi.

5. Peningkatan kualitas dan kuantitas sarana dan prasarana pendukung seperti WC umum dan mushola.

6. Penggunaan lahan untuk alokasi sebagai tempat perdagangan dan pusat kegiatan.

7. Peningkatan kualitas sumber daya manusia (SDM) dengan memberi pelatihan dalam bidang kepariwisataan unuk meningkatkan partisipasi masyarakat.

8. Kurangnya investasi dalam menambah sarana dan prasarana yang mendukung perkembangan kawasan desa wisata.

Pada penelitian didapatkan beberapa faktor pengembangan temuan baru, diantaranya:

1. Media promosi

2. Pengelolaan dari masyarakat setempat

3. Kebijkan pemerintahan dalam pengembangan kawasan desa wisata

Berdasarkan hasil literasi analisis delphi didapatkan faktor-faktor pendukung pengembangan kawasan desa wisata. Maka faktor-faktor pendukung pengembangan Desa Tulungrejo sebagai desa wisata, adalah:

1. Kegiatan sehari-hari masyarakat dalam bertani, english day,beternak ikan koi dan lele sebagai daya tarik desa wisata di Desa Tulungrejo.

2. Mempertahankan kesenian tradisonal yang ada sebagai simbol di kehidupan masyarakat Desa Tulungrejo sebagai daya tarik desa wisata.

3. Menjadikan Edukasi Dalam Bercocok Tanam, Mempelajari Tentang Pertanian, Mempelajari Cara beternak ikan air tawar.

4. Peintegrasian aksesbilitas menuju Desa Tulungrejo.

5. Meningkatkan kualitas dan kuantitas sarana dan prasarana pendukung seperti WC umum dan mushola di tempat wisata.

6. Mengalokasikan penggunaan lahan untuk dijadikan kegiatan perdagangan dan jasa yaitu rumah makan dan toko souvenir.

7. Peningkatan kualitas sumber daya manusia (SDM) memberi pelatihan dalam bidang kepariwisataan untuk 
meningkatkan partisipasi masyarakat dalam kegiatan wisata di Desa Tulungrejo.

8. Menyediakan tempat hiburan dan rekreasi tanpa merubah nilai, budaya dan norma yang ada di Desa Tulungrejo.

9. Media promosi sebagai pengenal kawasan desa wisata di Desa Tulungrejo ke masyarakat luar.

10. Pengelolaan dari masyarakat setempat agar ikut berperan aktif dalam pengembangan kawasan desa wisata.

11. Kebijakan pemerintah dalam mengontrol pengembangan kawasan desa wisata di Desa Tulungrejo.

\section{B. Arahan Pengembangan Desa Wisata Desa Tulungrejo.}

Arahan pengembangan desa wisata menggunakan arahan deskriptif kualitatif berbentuk narasi.Hasil narasi diambil dari sasaran pertama dengan mengkomperasikan teori terkait dan tinjauan kebijakan.

Didapatkan hasil arahan pengembangan desa wisata Desa Tulungrejo yaitu arahan pengembangan secara spasial dan non spasial yaitu :

Secara spasial, arahan pengembangan kawasan desa wisata di Desa Tulungrejo antara lain sebagai berikut :

1. Meningkatkan jumlah wisatawan yang berkunjung ke desa wisata di Desa Tulungrejo dengan cara menyediakan paket wisata dan meningkatkan sarana dan prasarana berupa homestay atau penginapan yang bisa digunakan oleh wisatawan untuk singgah di Desa Tulungrejo guna memperkenalkan kegiatan sehari-hari masyarakat yang dapat dilihat dan dinikmati secara langsung.

2. Memudahkan wisatawan yang berkunjung ke desa wisata Tulungrejo, diperlukan pembangunan lahan parkir komunal yang akan diintegrasikan dengan angkutan umum yang ada di desa wisata Tulungrejo

3. Sarana wisata yang sangat menentukan bagi pengembangan kawasan wisata diperlukan penyediaan fasilitas pendukung dan penunjang wisata di setiap obyek wisata yang belum terdapat mushola dan MCK untuk membuat wisatawan dapat lebih lama tinggal di tempat wisata.

4. Memperluas kawasan perdagangan dan jasa guna menunjang usaha kreatif masyarakat serta membukan kesempatan kerja bagi masyarakat. Sehingga dapat meningkatkan pendapatan masyarakat sekitar.

5. Mengembangkan kawasan desa wisata di Desa Tulungrejo dengan konsep Community-Based Tourism (CBT) dimana masyarakat dilibatkan dalam hal perencanaan, pelaksanaan dan juga pengawasan dari kegiatan wisata yang ada nantinya. Peran aktif masyarakat dalam menyampaikan pendapat tentang pengembangan kawasan yangdiinginkan oleh masyarakat sangat dibutuhkan, tentunya tetap memperhatikan dan menjaga citra dan identitas kawasan

6. Perumusan peraturan daerah yang mengatur tentang tata guna lahan yang diperbolehkan dengan menyesuaikan dengan kondisi eksisting di kawasan desa wisata di Desa Tulungrejo

Sedangkan secara non spasial arahan pengembangan kawasan desa wisata di Desa Tulungrejo antara lain sebagai berikut :

1. Mempertahankan keaslian kesenian dan kebudayaan tradisonal Desa Tulungrejo dengan mengadakan pertunjukan kebudayaan lokal dan menjadikannya sebagai daya tarik wisata utama di kawasan desa wisata Tulungrejo

2. Menunjukkan ciri khas dan keunikan desa Tulungrejo yang membedakan terhadap desa lainnya dengan menjadikan Desa Tulungrjeo sebagai desa wisata edukasi khususnya dalama untuk mempelajari tentang pertanian, mempelajari cara beternak ikan air tawar dan menjadikannya sebagai wisata utama di kawasan desa wisata di Desa Tulungrejo.

3. Sebagai daya tarik desa wisata, wisata kuliner juga dijadikan sebagai objek wisata pendukung langsung kawasan desa wisata. Kuliner yang disajikan adalah makanan khas Desa Tulungrejo dengan suasana rumah makan pedesaan dan terjaga kebersihannya.

4. Pengadaan lokakarya dan sosialisasi berkala dan pemberian intensif kepada masyarakat Desa Tulungrejo guna menunjang berkembanganya desa wisata Tulungrejo. Mengedukasi masyarakat dengan cara memberikan contoh desa wisata kesuksesan pengembangan kawasan desa wisata di kawasan lain. Di dalamnya ada penjelasan peran pentingnya masyarakat kawasan wisata terhadap berkembangnya kawasan desa wisata tersebut.

5. Mengadakan kerja sama dengan pihak swasta dengan memberikan kemudahan atau insentif dalam prosedur investasi seperti memberikan kemudahan ijin usaha bagi investor yang nantinya akan membuka usaha di kawasan, dengan syarat jenis usaha yang sesuai dengan tema kawasan dan tidak merugikan masyarakat

6. Mengadakan kerja sama dengan media informasi seperti radio, televisi lokal ataupun pembuatan web khusus sebagai upaya branding tentang desa wisata Tulungrejo guna menarik wisatawan baik lokal maupun internasional dan juga untuk meningkatkan pemasaran produk lokal dari desa wisata Tulungrejo.

\section{KESIMPULAN}

Berdasarkan hasil penelitian, maka dapat disimpulkan bahwa kegiatan sehari-hari masyarakat yaitu bertani sebagai ciri khas. Dengan adanya hal tersebut maka desa ini sangat berpotensi menjadi kawasan desa wisata agrowisata dengan arahan sebagai berikut:

1. Desa Tulungrejo memiliki potensi lokal, dapat diarahkan sebagai desa wisata berbasis agrowisata.

2. Memperluas kawasan perdagangan dan jasa,

3. Memberikan pelatihan terhadap masyarakat guna meningkatkan kualitas sumber daya manusia.

4. Mengembangkan kawasan desa wisata di Desa Tulurejo dengan arahan komsep Community-Based Tourism (CBT).

5. Membuat peraturan daerah guna mengatur tentang tata lahan di kawasan desa wisata.

6. Memperthankan dan menunjukan ciri khas keaslian kesenian kebudayaan tradisional Desa Tulungrejo.

7. Mengadakan lokakarya dan sosialisasi kepada masyarakat guna menunjang berkembangnya desa wisata Tulungrejo

8. Mengadakan kerja sama dengan pihak swasta sebagai investor dengan syarat dan kententuan yang sudah ditetapkan

9. Mengadakan kerja sama dengan media informasi guna mempromosikan desa wisata Tulungrejo. 


\section{DAFTAR PUSTAKA}

[1] BPS, Buku Pariwisata dan Pengertian. 1991

[2] R. Adisasmita, Pembangunan Pedesaan. Yogyakarta: Graha Ilmu, 2013.

[3] BPS, Badan Pusat Statistik Nasional. 2010.

[4] Suharsono, Pendekatan Pengembangan Kepariwisataan. Jakarta: P3O-LIPI, 2009.

[5] W. Nuryanti, Concept, Perspectiv and Challenges. Yogyakarta: Gadjah Mada University Press, 1993.

[6] R. K. Kediri, Bappeda Kabupaten Kediri. 2010

[7] Pusat Informasi Kampung Inggis. 2014.

[8] C. A. Gunn, Tourism Planning. New York City: Taylor and Francis, 2002.

[9] S. Imam Asy'ari, Sosiologi Kota dan Desa. Surabaya: Usaha Nasional Surabaya, 1993.

[10] D. Sugiyono, Prof, Metode Penelitian Pendidikan (Pendekatan Kuantitatif, Kualitatif, R\&D). Bandung: Alfabeta, 2006. 